\title{
Marica Bodrožić: Hybridity, Language, and Cultural Identity
}

\begin{abstract}
This contribution aims to analyse the characteristic use of the German language in the works of Marica Bodrožić, one of the many authors of transcultural literature. Through a distinctive use of language, this author is able to depict the in-between condition and hybrid identity of migrants who, because of their personal experience, deal with different cultures and languages. Starting from her personal situation and describing her experience with the German language, Bodrožić comes to the conclusion that hybridity is actually shared by all people since it is intrinsic in language and identity. Boundaries between countries, cultures, and human beings are merely inventions that produce fear of what is perceived as diverse. What is distinctive about Bodrožić is her ability to use German in a dynamic and original way, thus creating a surprising effect. Her works reveal that cultural mixing produces interesting results both in themes and style.
\end{abstract}

Keywords: hybridity, identity, language, migration

\section{How migration shapes identity: Marica Bodrožić, a transcultural writer}

This study focuses on the distinctive usage of the German language in the works of Marica Bodrožić as an expression of the hybrid identity which mirrors the in-between condition of migrants. The literary production of this author is permeated by discourses on the definition of human identity in relation to the experience of migration and cultural blending; nevertheless, as will be shown through Bodrožić's works, hybridity is a condition belonging to all people regardless of whether they are migrants or not. These topics are central to the current historical period, in which migratory flows are responsible for deep changes in societies, especially in Europe. Above all, it must be taken into account that Bodrožić has personally experienced the reality of migration, and consequently offers a distinctive point of view on this phenomenon. Migration represented a milestone in her life, contributing to the definition of her identity. Bodrožić has Yugoslav origins, since she was born in 1973 in Svib in Croatian Dalmatia. It must be remembered that modern Croatia did not exist before 1991, since it was part of the former Yugoslavia. Bodrožić spent her childhood there with her grandparents. Meanwhile,

Ә Open Access. (C) 2021 Elisabetta Vinci, published by De Gruyter. (c) BY-NC-ND This work is licensed under the Creative Commons Attribution-NonCommercial-NoDerivatives 4.0 International License. 
her parents lived in Germany, where they had moved to work as Gastarbeiter, immigrant workers. In 1983, Bodrožić joined them and left her native country to live in Frankfurt. Until that moment, German was a secret language spoken by her parents but foreign to her, then it became her "second mother tongue," as she herself claimed. Her migration from Dalmatia to Germany became the symbol of a new life and of a new language, as will be explained below.

Because of her life experience, Bodrožić can be categorized as a transcultural or intercultural writer. Actually, though, the authors belonging to this category are very heterogeneous and have different backgrounds. For this reason, there is no suitable definition for classifying this eclectic group, despite several attempts to find one: "Ausländerliteratur," "Migrationsliteratur," and "Gastarbeiterliteratur," among others (Drossou and Kara 2009, 4). In order to shed light on this diversity, Carmine Chiellino (2007, 55-57) tried to classify these authors into subcategories that he called "Stimmen." He identified various types under this rubric: authors who describe their migration experience in their mother tongue, others who choose German as a literary language, and others still who speak German as a mother tongue but use the language of their background in family contexts. This clear need for new definitions is the expression of a great change in both social and literary fields; indeed, terms like "transculturality" and "interculturality" have emerged because of a change in the concept of culture, as Wolfgang Welsch $(1994,88)$ claimed: "Der alte Kulturbegriff, der auf Homogenität innerhalb der Kulturen und auf klare Abgrenzbarkeit zwischen ihnen setzte, ist, zusammengefaßt gesagt, ob der inneren Komplexität wie der äußeren Vernetzung heutiger Kulturen deskriptiv falsch geworden.” In other words, there are no more fixed boundaries between cultures. Marica Bodrožić is only one of several authors that develop these themes, but what is distinctive about her writing is its description of the in-between condition experienced by migrants, which is conveyed through a particular use of language; moreover, her works show a blending of both cultures and languages due to her personal experience. Starting with her migration, her whole life has been marked by two cultural backgrounds, the Yugoslav one and the German one. Human identity, in fact, is subjected to profound changes depending on the environment and our interaction with it, so that turning points - like migration - have a deep influence on the formation of the self (Strauss 1959, 93-94). Bodrožić's works have met with approval from readers and critics: she won the Heimito von Doderer Prize in 2002 and the Adelbert von Chamisso Prize, dedicated to "outstanding German-language authors whose work is shaped by a change of culture" ("Adelbert von Chamisso Prize of the Robert Bosch Stiftung” n.d.). In 2007 she also received the Kunstpreis Berlin, then the Kulturpreis Deutsche Sprache; and in 2011, her poetry production was awarded with the Liechtenstein-Literaturpreis für die Sparte Lyrik. 


\section{Dichotomies: Two cultures connected through language}

Marica Bodrožić's works are marked by the presence of thematic dichotomies, an expression of her hybridity as human being and writer, which are typical of migrants. Such dichotomies symbolize the presence of two cultures and traditions that are connected through language. Indeed, the aim of this article is to demonstrate the distinctive use of language in Bodrožić's works in depicting the condition of people who have experienced migration and, as a consequence, deal with different cultural contexts. Some of the dichotomies include past and present, Yugoslavia and Germany, childhood and adulthood, and silence and voice, and all of them display a strong connection with language: the past is the period of her childhood in Yugoslavia and is related to the Yugoslav language, and the present is the time of her adulthood in Germany and is characterized by the discovery of her second mother tongue. Particularly relevant is the voice-silence dichotomic pair. Silence corresponds to the world of Bodrožić's childhood, which was to be expressed only later through her literary voice, which was German: "die deutsche Sprache ist der Mittelpunkt und der Schlüssel der Werke von Marica Bodrožić” (Braun 2009, 1). Moreover, as Claudio Magris (2008) has pointed out, she only can talk about her past, and express her Slavic background that has been removed, by writing in German.

Some examples of dichotomies and language in her literary production will be provided. The starting point for the short-story collection Tito ist tot is the death of Josip Broz Tito, which represents a major divide for Marica Bodrožić: not only does it mark the end of an age for Yugoslavia, but it is also relevant for the author's biography - Tito died in 1980, and she moved to Germany in 1983. Therefore, a parallelism can be traced between the political events of her country and the author's life, as if they were a macro- and a microcosm in relation to each other. Above all, the political changes occurring in Yugoslavia overlap with Bodrožić's language switching to German, which allowed her to become part of a new world. Thus, the historical event in the book's title is a symbolic divide between her life before and after her migration, between childhood with her grandfather and adulthood with her parents, above all between the first mother tongue and the second one, thus highlighting how language is connected to all aspects of life and mirrors the experience of it.

The novel Der Spieler der inneren Stunde (Bodrožić 2005) is based on the journey of the main character, Jelena, who moves from Dalmatia to Germany, mirroring Bodrožić's journey. The journey has various meanings and, even in this case, a link with language can be traced: on the one hand, the journey symbol- 
izes separation from the native country and, as a consequence, from the mother tongue and Serbo-Croat culture; on the other hand, it implies the new experience of landing in an unknown country and the beginning a new life marked by the German language. This issue also plays a pivotal role not only in Sterne erben, Sterne färben, as will be highlighted in the next paragraph, but also in other works by Bodrožić, such as Mein weißer Frieden, thus characterizing her whole production. The journey is, for Bodrožić, a metaphor for life, as she writes: "Das Leben ist eine Reise, die sich selbst überschreibt, jeder Gedanke, jede Empfindung ist ein neuer Weg, der den eigenen Kern freilegt und die Sinne verfeinert” (Bodrožić $2014,11)$. Thus, the journey represents the passage from one culture to another one and the discovery of a new language. In this regard, another emblematic image is that of the bridge, which frequently appears in Marica Bodrožić's works: since dichotomies permeate her writing, bridges are necessary to connect them. In this sense, the act of writing, and language itself, represent a metaphorical bridge between past and present: Croatia and Germany, and of course the Serbo-Croat and German languages. In other words, Bodrožić's language mirrors the condition of hybridity and cultural mixing experienced by people that, like her, have left their native country to start a new life in another place. In order to explain how this happens, the next section will be devoted to the analysis of Sterne erben, Sterne färben, in which language best expresses hybrid identity and cultural diversity.

\section{Language as a bridge: Sterne erben, Sterne färben}

The main issues in Marica Bodrožić's works can be observed in the novel Sterne erben, Sterne färben: Meine Ankunft in Wörtern, published in 2007 by Suhrkamp. In this novel, her condition of hybridity and foreignness is expressed by language which is relevant to the development of identity. In this interpretation, Sterne erben, Sterne färben has been defined as a "literarische Sprachbiographie," a biography narrated through language, that highlights the essential role of language in the life of the narrator (Thüne 2010, 76). In the nineteen chapters of the book, Bodrožić relates memories of her past in Yugoslavia and episodes of her life in Germany and in France, marked by the use of different languages (Serbo-Croat and German in particular), words, and sometimes even letters. "Le parole, le stesse lettere dell'alfabeto hanno sfumature, colori, irradiazioni diversi; dicono la vita ma anche la creano, diventano i lineamenti di chi scrive," claims Magris (2008), and that is exactly what happens in this novel: 
In meiner ersten Muttersprache heißt das Wort für Liebe ljubav, auch hier bringt der Buchstabe L es ins Sichtbare, bringt es, so zeigt sich in diesem Buchstabenbild, hinüber in das Land des Buchstaben J, der zu großen Teilen in der Erde lebt, dort, wo die Wurzeln der Pflanzen und Bäume verwandt sind mit den Küssen, wo sie sich und die Zukunft ihrer Farben besprechen. Dieser Buchstabe begibt sich ins Erdige wie eine Suppenkelle, um später wieder etwas Neues zu werden. (Bodrožić 2007, 14-15)

This passage is an example of how the precise use of letters and words metapoetically reflects the deep questions of Bodrožić's life. She has the ability to analyse German words, finding original connections among them, as in the following quotation:

Im Deutschen wollte die Tradition mir überhaupt nicht einleuchten, womöglich, weil in dieser Sprache die Wunde und das Wunder so nahe beieinanderliegen, als wärmte das eine Wort schon die Ankunft des anderen vor, damit die Zukunft eine Sache und Wirkkraft eines einzigen Buchstabens und mit ihm der Ewigkeit würde [...]. Erklären läßt es sich nicht, doch über diese beiden Wörter, mit dem Bedarf der Lungen gebeugt, verstehe ich gleichsam Zellkern für Zellkern, daß nicht Leben und Tod, aber Leben und Sterben jene beiden Gegensatzpaare sind, die jeden gehenden Menschen in den Abschied einführen. (Bodrožić 2007, 21-22)

Language is the main character of the book, as Bodrožić $(2007,1)$ herself claims: "die Deutsche Sprache baut in mir an einem Gerüst, an einem Lobgesang; an der Erinnerung der Seele." Similarly, Klaus Hübner (2009) wrote: "Sterne erben, Sterne färben ist eine Art Liebeserklärung an die Möglichkeiten der deutschen Sprache, an ihre Musikalität und ihre Formenvielfalt." German has become the language that allows her to express herself and gives her comfort and protection: "Nur mit dem Schutzdamm der deutschen Sprache konnte ich vor dem Fernseher meine eigenen Tränen zurückhalten," "erst in der deutschen Sprache wird mein eigenes Zuhause für mich selbst hörbar," and "Das Deutsche wurde immer mehr zu einem wärmenden Kleidungsstück” (Bodrožić 2007, 27, 1, 95). These quotations demonstrate the prominent role of language, but its connection to the concepts of hybridity and identity has not been discussed yet in this article. Starting from Wittgenstein, much philosophical, linguistic, and cognitive research on language has revealed that it shapes thought and cognition. On the one hand, language is culturally determined; on the other hand, it influences the individual mind and also has, as a result, implications for the building of identity. In her works, Bodrožić creates a strong link between language, identity, and outsider status, since her own life has been marked by switching and mixing languages. Moreover, language is the medium through which this author understands being different from other people. Different use of languages marks diversity between one person and another, thus allowing the author to develop her individual identity 
in contrast to the identity of others. It was through her mother tongue that Marica Bodrožić first experienced the sense of being an outsider:

Da wir zwischen Dalmatien und der Herzegovina aufwuchsen, lernten wir die Dialekte beider Gegenden. Einmal entzündete sich im dalmatinischen Dorf ein Gelächter an dem herzegovinischen Wort für Handtuch, peškir. Meine Schwester hatte es gesagt. Ich glaube, es gefiel ihr besser als das Wort ručnik, wie es im Hochkroatischen hätte richtig heißen müssen und wie die Leute in Dalmatien es auch gebrauchten. Zwei grundverschiedene Wörter waren das also, und je nachdem, in welcher Gegend wir das eine oder das andere sagten, wußte man gleich, ob wir Fremde oder Zugehörige sind. Natürlich geschah uns Kindern immer die Fremdheit, wir hatten immer das Gespür für sie. (Bodrožić 2007, 62)

Bodrožić writes that "Fremdheit" was already present in her childhood, since she felt an outsider in her native tongue too. Even if the author presents a personal situation of being in-between, she also comes to the conclusion that "Fremdheit" is a natural human condition and that all people experience their foreignness in certain contexts, regardless of language and nationality.

Serbo-Croat plays an important role in Bodrožić's life and in the novel as well. If at the beginning it is only an interior language, it later becomes a basis for comparison with other languages. This becomes clear when the author learns French: she realizes that Serbo-Croat is like a hidden current and that, when she learns new French words, she compares them to terms from her native country rather than to German ones, thus confirming that Serbo-Croat can be defined as a mother tongue: "Als habe die erste Sprache ihr Mitspracherecht nun endlich erfolgreich in mir etabliert, hörte ich zu allen neuen französischen Wörtern die ersten muttersprachlichen. Die Fugen klafften, offen lag vor mir eine ganz alte Musik" (Bodrožić 2007, 69). Furthermore, the interior flow of her first mother tongue appears when she meets other Yugoslav people. She hears the "Jugo-Ton" (Bodrožić 2007, 43) in their pronunciation and recognizes her compatriots by their gestures: "An der Haltestelle hatte ich an der Art, wie der Mann auf den Boulevard schielte und immer wieder nach dem Bus Ausschau hielt, etwas Jugoslawisches in ihm gesehen” (Bodrožić 2007, 73). Even if Yugoslavia does not exist anymore, a sense of affinity among Yugoslavs persists. This proves that identity cannot be defined by geographical or political boundaries, for it is something hybrid, subject to continuous transformation. Only identity papers try to fix our identity, our role in the world, which is actually impossible to define: "Aber der antrainierte nationale, geographische Reflex macht uns glauben, wir bräuchten eine nationale Identität. Warum sagen wir nicht, wir brauchen eine Orientierung und wir möchten sie Identitätskarte nennen? [...] Wie unbesitzbar Nationalität ist, merkt jeder, der sich nun ein bißchen hinauswagt, weg aus seiner staubig kleinen, hinein in eine größere Welt” (Bodrožić 2007, 56). 
Thus, as Homi Bhabha claimed, "any specific sense of national identity is finally delusive" $(1994,40)$, and all the argumentations used by nationalism are just historical invention (Gellner 1983). As well as identity, Bodrožić affirms that language and even her first mother tongue have a hybrid nature:

\begin{abstract}
Und aus was genau bestand eigentlich meine erste Sprache? War sie nicht immer schon etwas Hybrides, etwas durch und durch Unvollkommenes, aus Kreuzungen und Ahnungen bestehendes Gemisch aus dem dalmatinischen Dialekt, der Sehnsucht nach einem hochkroatischen Sprachfluidum, wie es die Leute in der Hauptstadt um sich herum verbreiteten, aus herzegovinischen Wortendungen, Redensarten von hier, Redensarten von dort. (Bodrožić 2007, 96-97)
\end{abstract}

Her migration and the consequent language-switching represent a rebirth for Marica Bodrožić, and so it can be stated that the German language, in particular through the act of writing, serves as a bridge between past and present life, as the author indeed explains: "Das Schreiben ist jetzt eine Brücke zwischen dem Land des Schweigens, meinen Wörtern und dem lauten Gehege meiner Stimme. Die Brücke läßt mich alles auf dem Papier sagen. Die Brücke ist meine freundliche Stille, in der ich alles entwickeln kann, ohne zu früh einen Schreck vor der eigenen Stimme und der zu ihr gehörigen Klangfarbe zu bekommen” (Bodrožić 2007, 102).

German is the conjunction between the inexpressible past in Yugoslavia, meaning the dictatorship of Tito, and the present in which Bodrožić begins writing, and thanks to this language she can evoke pictures and people from her childhood. Not only is the German language a bridge between opposite concepts; it also is a bridge between the cultures the author is immersed in: Bodrožić (2007, 96) describes elements of Serbo-Croatian culture only in German: "Das Durchschreiten beider Sprachen kam mir manchmal vor wie zweifaches Leben, wie zwei autonom nebeneinander wirkende Lebensspuren, die zu verbinden mir nur im Schreiben gelang." What is interesting in the case of Bodrožić is the definition of German as a "zweite Muttersprache" (Bodrožić 2007, 127): even if she rejects labels, the choice of this concept indicates the importance of the German language in her life, a language in which she can express her pain, her suffering, her past; a language which lends her comfort and safety, as a mother tongue does. But, in opposition to Serbo-Croat, the second mother tongue acts as a filter, since it allows the author to narrate episodes of her past while avoiding Sehnsucht and sadness, thus giving her the freedom of narration. To this extent, it can be affirmed that the process of hybridization is totally completed in Bodrožić linguistic experience, which may be representative of people emigrating from their native country and experiencing the beginning of a new life marked by a new language. 


\section{Hybridity and creativity}

As already pointed out, language is a privileged means for expressing the condition of hybridity; in this specific case, it serves as a conjunction between cultures. The concept of hybridity permeates many different fields of study, but it has been correlated to literature and language following the process of decolonization and globalization in the twentieth century. As Robert Young explains in his work Colonial Desire (1995, 4), "the globalization of imperial capitalist powers, of a single integrated economic and colonial system, the imposition of a unitary time on the world, was achieved at the price of the dislocation of its people and cultures." As a result, anxiety about racial difference increased and produced situations of instability and conflict, causing the search for a fixing of identity against fragmentation. Today, the situation is quite different because modern societies are self-conscious of their identity made up of heterogeneity, hybridity, and cultural exchange. In modern theory, hybridity is often considered as a space of negotiation between cultures. In this perspective, third-space theory plays a fundamental role. It was introduced by Homi K. Bhabha (1994), who claims that all forms of culture are continually in a process of hybridization and there is always a process of exchange and a negotiation of boundaries and cultural identities.

In other words, hybridity is a space of blending, and Bodrožić is able to make this visible through language. Even though language is intrinsically hybrid, as Bhabha says, she uses it in an original way and creates a blend of the two cultures that shaped her as human being and writer. In particular, Bodrožić plays with compound words. German is a very flexible language, since it allows new words to be created through the combination of different terms, but this author combines words in an unusual way, thus creating strange matches such as "Windsammler," "Bildinspektor," "Zauberfrauen," "Hautnachbarschaft," "Echoraum," "Wortbild," "Buchstabpulver," "Sprachschritt," "sommerdarbend," "Sprachmensch-sein." The novel Sterne erben, Sterne färben contains lots of these words, which produce surprise in readers and give them the possibility of metacritically reflecting on their sense of language. Sometimes these creative words are difficult to understand for German people too, as is the case with the ambiguous term "Schicksalspieler": it could indicate people who play with destiny or people who defy destiny. Moreover, the formation of compound words can be used to obtain an ironic effect, as in case of the words "Zungengymnastiker" and "Angstgaumen." The former indicates people who are not able to pronounce words correctly; the latter is a sort of provocation, a combinations of the words for "fear" and "palate," but Bodrožić uses it to refer to people who are afraid of diversity and show their fear when they have to pronounce foreign names, such as that of the author: "Die Leute haben Angst vor allem, was sie nicht kennen, und mein dachgeschmücktes 
$z$ und mein Vogellandeplatz des $c$ in meinem Nachnamen macht die Menschen schon aus der Ferne schwitzen. Mehrfach sprachen sie den Namen beispielsweise vor meinen Lesungen richtig aus, Marica schien dabei das Leichteste zu sein" (Bodrožić 2007, 142-143).

Cultural diversity often provokes fear, as can be experienced in contemporary society. Even the symbols of the Serbo-Croat alphabet become a source of fear for people who cannot pronounce the surname "Bodrožić." But the real difficulty is actually hidden behind the author's name, "Marica”: most people pronounce it Marika, making a mistake: "Das Wasser, schon in den ersten drei Buchstaben, war steter Begleiter und innerer Beschützer vor dem Klangraum des an sich schönen, windverteilenden Buchstaben $k$; der mich aber in Sekundenschnelle zur gnadenlos daherkommenden Marika machte und dadurch einen unangenehmen Geschmack offenbarte” (Bodrožić 2007, 144). Through this example, the author mocks the unjustified fear of her foreign origin. The language used by Marica Bodrožić is very poetic in the etymological sense: after all, the Greek verb poiein means "to create." This author creates new words and, as a result, new concepts and images. In this sense, her works - and the act of writing too - are connected to cultural diversity and hybridity: her linguistic mastery of both German and Serbo-Croat allows her to mix two different Weltanschauungen through word formation, thus tracing a connection between bilingualism and creativity. Furthermore, Bodrožić has an apparently naive approach to the German language, which allows her to look beneath the surface of the meaning established by usage and rediscover original roots, with the result that she is able to notice details that German natives do not grasp: "Das deutsche Wort Leib und, wenn nur ein Buchstabe vertauscht wird, der Imperativ Lieb! darin. Welche Vernarrtheit ich im Deutschen entwickele, die Buchstaben zu verdrehen” (Bodrožić 2007, 137).

\section{Conclusions}

To conclude, it can be stated that, in the literary works of Marica Bodrožić, the topic of hybrid identity is closely linked to multilingualism, for, according to Zafer Şenocak (2011), roots are multilingual. ${ }^{1}$ Moreover, Marica Bodrožić’s writing can be considered a form of provocation to readers and, in particular, to German native speakers. She demonstrates that the German language can

1 In the dedication of his Deutschsein, Şenocak (2011) writes: "Für meinen Vater, der mich gelehrt hat, dass Wurzeln mehrsprachig sind.” 
become hybrid, as the language of her childhood was. On the one hand, this is possible thanks to her ability and creativity; on the other hand, it is possible because hybridity is something intrinsic to language. Like language and identity, the concept of homeland cannot be exactly defined either. The author considers the whole world her homeland, for she writes that "ich mit der Formulierung 'mein Land' immer die ganze Erde gemeint [hatte]” (Bodrožić 2007, 87). As a consequence, geographical and linguistic boundaries lose their roles and nationality becomes a worthless concept. Language also represents a powerful means of communication for showing how important and positive the mixing of cultures can be. In this sense, the works of Marica Bodrožić, in particular Sterne erben, Sterne färben, draw attention to current questions, such as migration, integration, and cultural diversity: "Fürchtet euch nicht! Ne soyez pas crainte. Das Unbekannte hat ein eigenes Alphabet. Man kann es erlernen wie das Autofahren, wie das Hosen- und Röckebügeln, wie das Putzen, das Denken, das Lesen. Das Unbekannte ist nicht das Fremde. Es ist das Neue. Das zu Erkennende. Das bereits Vorhandene. Das Wissende. Das uns Leitende. Das Eigene, ja, auch” (Bodrožić 2007, 143).

Even the unknown is compared to a language with its own alphabet, and like a foreign language it only has to be learnt to overcome fear. In other words, being open-minded is the only way to know other traditions and to understand that even our own culture can be perceived as different by other people because everything depends on point of view. Finally, the works of Bodrožić demonstrate how a personal experience can become a symbol of a more general condition, for human life is a journey and human beings are travellers in the world. Marica Bodrožić uses her writing and language to express a strong message of openness towards diversity, that, as anticipated, can be experienced by all of us; her literary works are an exemplary demonstration of the richness generated by cultural mixing: thanks to Bodrožić, the German language earns new words, German literature a new author.

\section{Works cited}

"Adelbert von Chamisso Prize of the Robert Bosch Stiftung." n.d. https://www.bosch-stiftung. de/en/project/adelbert-von-chamisso-prize-robert-bosch-stiftung (30 December 2018).

Bhabha, Homi K. The Location of Culture. London: Routledge, 1994.

Bodrožić, Marica. Der Spieler der inneren Stunde. Frankfurt am Main: Suhrkamp, 2005.

Bodrožić, Marica. Sterne erben, Sterne färben: Meine Ankunft in Wörtern. Frankfurt am Main: Suhrkamp, 2007.

Bodrožić, Marica. Mein weißer Frieden. Munich: Luchterhand Literaturverlag, 2014. 
Braun, Michael. "Lesung von Marica Bodrožić." II. Fachtagung der Konrad-Adenauer-Stiftung für europäische Germanisten, Berlin. 25 September 2009. Address. https://www.kas.de/ c/document_library/get_file?uuid=86db33a0-def8-319e-18ba-7a3c8230a965\&groupld= 252038 (15 November 2017).

Chiellino, Carmine. Interkulturelle Literatur in Deutschland: Ein Handbuch. Stuttgart: Metzler, 2007.

Gellner, Ernest. Nations and Nationalism. Oxford: Blackwell, 1983.

Hübner, Klaus. "Der Plural ist mein tägliches Brot: Marica Bodrožić - eine deutsche Dichterin aus Dalmatien.” Literaturkritik.de 1 (2009). http://literaturkritik.de/public/rezension. php?rez_id=12587 (3 November 2017).

Magris, Claudio. “Marica Bodrožić, dalmata di Germania, e la tragedia della sua terra." Corriere della Sera 3 September 2008: 40.

Drossou, Olga, and Sibel Kara. "Vorwort." Migrationsliteratur: Eine neue deutsche Literatur. Berlin: Heinrich-Böll-Stiftung, 2009. 4. https://heimatkunde.boell.de/sites/default/files/ dossier_migrationsliteratur.pdf (30 December 2018).

Şenocak, Zafer. Deutschsein: Eine Aufklärungsschrift. Hamburg: Körber-Stiftung, 2011.

Strauss, Anselm Leonard. Mirrors and Masks: The Search for Identity. New Brunswick: Transaction Publishers, 1959.

Thüne, Eva-Maria. "Sprachbiographien: Empirisch und literarisch.” Polyphonie - Mehrsprachigkeit und literarische Kreativität. Ed. Michaela Bürger Koftis, Hannes Schweiger, and Sandra Vlasta. Vienna: Praesens, 2010. 59-80.

Young, Robert J. C. Cultural Desire: Hybridity in Theory, Culture, and Race. London: Routledge, 1995.

Welsch, Wolfgang. "Transkulturalität - Die veränderte Verfassung heutiger Kulturen.” Sichtweisen: Die Vielheit in der Einheit. Ed. Freimut Duve. Weimar: Stiftung Weimarer Klassik, 1994. 83-122.

Elisabetta Vinci, PhD, studied foreign language and literature at the University of Catania (Italy), where she concluded her doctorate in Cultural Heritage. Her dissertation focuses on comparison between central European and Sicilian puppetry, in order to show the common roots of this heritage. Her research interests and publications concern German literature, theatre, and cognitive narratology. 
